\title{
PENGARUH KONSENTRASI INHIBITOR EKSTRAK DAUN GAMBIR DENGAN PELARUT ETANOL-AIR TERHADAP LAJU KOROSI BESI PADA AIR LAUT
}

\author{
Rozanna Sri Irianty dan Maria Peratenta Sembiring \\ Jurusan Teknik Kimia, Fakultas Teknik, Universitas Riau \\ Kampus Binawidya Jl. HR. Subrantas Km. 12,5 Pekanbaru 28294 \\ Email : rozannasriirianty@ymail.com
}

\begin{abstract}
The important properties to overcome the corrosion are safe, available, biodegradable, low cost, and environmental friendly. Gambier leaves extract is one of the inhibitor that have environmental friendly properties. This study aims to determine the effectiveness of extract using ethanol-water to reduce the corrosion rate. Soaking of ferrous iron plate samples in seawater media have done for corrosion test. Agitator and aerator motors at turn-on and conducted a series of immersion with varying contact time 5, 10, 15, and 20 days. After the time up next ferrous iron plate samples were cleaned, dried, and weighed. Experiment was repeated by adding a inhibitor heavy leaves gambier extract with varying leaves gambier extract, 1000, 3000, and $5000 \mathrm{ppm}$. Soaking iron plate samples performed at varying $\mathrm{pH}$ at 3(acid), 6 (netral), and 9 (alkaline). Calculation is then performed and the rate of corrosion inhibition efficiency gambier leaves extract with ethanol-water solvent. On the immersion of iron plate without inhibitor, the result that the longer the contact time, the weight of the iron plate was reduced. The results showed the addition of inhibitors of leaves extract gambier with ethanol-water solvent into the corrosive media can reduce the rate of corrosion. Inhibitor of leaves extract gambier using ethanol-water solvent effective to reduce the rate of corrosion inhibitor at a concentration of $5000 \mathrm{ppm}$ and contact time of 20 days with the lowest value of the corrosion rate is $0.000503 \mathrm{~g} / \mathrm{cm}^{2}$ days in seawater media at initial $\mathrm{pH} 7.9$. Gambier extracts gave greatest inhibition efficiency about $60.345 \%$ obtained at a concentration of $5000 \mathrm{ppm}$ inhibitor and 20 days contact time.
\end{abstract}

Keywords : Corrosion, ethanol-water solvent, extraction, gambier leaves, inhibitors

\section{PENDAHULUAN}

Korosi merupakan peristiwa kerusakan atau penurunan kualitas suatu logam yang disebabkan terjadinya reaksi dengan lingkungan. Kerusakan karena korosi bisa mencapai 1000 kali lebih cepat pada logam. Oleh karena itu, timbul berbagai penelitian untuk melindungi logam dari pengaruh korosi, dari cara-cara yang sederhana hingga cara-cara yang paling modern dengan membuat logam paduan yang tahan terhadap korosi. Proses pencegahan korosi dapat dilakukan dengan melapisi permukaan logam, perlindungan katodik, penambahan inhibitor-korosi, dan lain-lain. Penambahan inhibitor korosi yang bersifat biodegradable merupakan solusi yang aman. Inhibitor korosi didefinisikan sebagai suatu zat yang apabila ditambahkan dalam jumlah sedikit ke dalam lingkungan akan menurunkan serangan korosi lingkungan terhadap logam. Umumnya inhibitor korosi berasal dari senyawa-senyawa organik dan anorganik yang mengandung gugus-gugus yang memiliki pasangan elektron bebas, seperti nitrit, kromat, fospat, urea, fenilalanin, dan senyawa-senyawa amina yang bersifat berbahaya dan tidak ramah lingkungan. Inhibitor korosi dari senyawa-senyawa organik dan anorganik ini dapat diganti dengan inhibitor dari ekstrak bahan alam yang ramah lingkungan.

Inhibitor dari ekstrak bahan alam merupakan solusi yang aman dan lebih tepat karena mudah didapatkan, biodegradable, biaya murah, dan ramah lingkungan ${ }^{[1]}$. Ekstrak bahan alam khususnya senyawa yang mengandung atom $\mathrm{N}$, 
$\mathrm{O}, \mathrm{P}, \mathrm{S}$, dan atom-atom yang memiliki pasangan elektron bebas. Unsur-unsur yang mengandung pasangan elektron bebas ini nantinya dapat berfungsi sebagai ligan yang akan membentuk senyawa kompleks dengan logam. Efektivitas ekstrak bahan alam sebagai inhibitor korosi tidak terlepas dari kandungan nitrogen yang terdapat dalam senyawa kimianya. Getah gambir yang diekstrak dari daun tanaman gambir (Uncaria gambir Roxb) mempunyai kandungan tanin sebesar 24,56\%. Tanin kaya akan senyawa polifenol yang mampu menghambat proses oksidasi. Polifenol merupakan senyawa turunan fenol yang mempunyai aktivitas sebagai antioksidan. Fungsi polifenol dapat sebagai penangkap dan pengikat radikal bebas dari rusaknya ion-ion logam. Tanin memiliki sifat antara lain dapat larut dalam air atau alkohol karena tanin banyak mengandung fenol yang memiliki gugus $\mathrm{OH}$, yang dapat mengikat logam berat.

Tanin adalah suatu senyawa polifenol dan dari struktur kimianya dapat digolongkan menjadi dua macam, yaitu tanin terhidrolisis (hidrolizable tannin) dan tanin terkondensasi

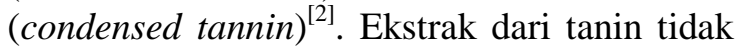
dapat murni $100 \%$, karena selain terdiri dari tanin ada juga zat non tanin seperti glukosa dan hidrokoloid yang memiliki berat molekul tinggi ${ }^{[3]}$. Tanin dapat diekstrak dengan menggunakan campuran pelarut campuran (bertingkat) atau pelarut tunggal. Umumnya tanin diekstrak dengan menggunakan pelarut air, karena lebih murah dengan hasil yang relatif cukup tinggi, tetapi tidak menjamin jumlah senyawaan polifenol yang ada dalam bahan tanin tersebut ${ }^{[4]}$. Untuk memperoleh ekstrak dengan kualitas dan kuantitas yang tinggi, maka umumnya digunakan etanol atau metanol dengan perbandingan volume air yang sebanding ${ }^{[5]}$. Dari sisi penggunaan pelarut, campuran etanol dan air dipilih untuk memperoleh jumlah bahan terekstrak yang lebih tinggi. Hal ini didukung dengan penelitian Rindit Pambayun ${ }^{[3]}$, dimana dengan campuran pelarut etanol dan air memiliki indeks polaritas lebih tinngi dari pelarut etanol saja. Hal ini juga sesuai dengan yang dikemukakan oleh Hagerman ${ }^{[4]}$ bahwa senyawa fenol pada umumnya sulit larut dalam air dingin. Dalam penelitian ini akan dilakukan uji efektifitas ekstrak daun gambir sebagai inhibitor organik dalam mengatasi masalah korosi pada logam.

\section{METODOLOGI PENELITIAN}

Bahan-bahan yang digunakan pada penelitian ini adalah daun gambir, plat besi, $\mathrm{HCl} 1 \mathrm{~N}$, $\mathrm{NaOH} 6 \mathrm{~N}$, air laut, dan akuades. Peralatan yang digunakan terdiri dari peralatan utama untuk uji korosi seperti terlihat pada Gambar 1.

\section{Variabel penelitian}

Variabel tetap pada penelitian ini terdiri dari ukuran plat besi yang digunakan dan suhu air laut. Plat besi yang digunakan untuk uji korosi berukuran $5 \times 2 \times 0,2 \mathrm{~cm}$ untuk tiap sampel. Plat besi ini direndam dalam air laut pada suhu ruang. Ekstrak daun gambir yang digunakan merupakan hasil ekstrak dengan menggunakan pelarut etanol-air. Variabel bebas dari penelitian ini meliputi konsentrasi inhibitor ekstrak daun gambir, waktu perendaman plat besi, dan $\mathrm{pH}$ air laut sebagai media korosi. Konsentrasi inhibitor ekstrak daun gambir divariasikan menjadi 1000, 3000, dan 5000 ppm. Waktu perendaman plat besi dilakukan selama 5, 10, 15, dan 20 hari. $\mathrm{pH}$ air laut yang digunakan divariasikan menjadi 3 (asam), 6 (netral), dan 9 (basa).

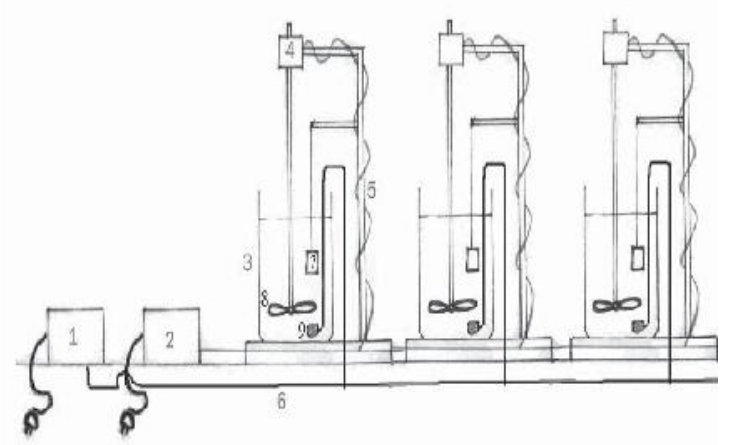

Gambar 1. Rangkaian peralatan utama untuk uji korosi

Keterangan :
1. aerator
6. statif
2. adaptor
7. sampel logam besi
3. labu
8. impeler
4. motor pengaduk
9. pemecah udara
5. statif 


\section{Prosedur Kerja}

\section{Persiapan sampel plat besi}

Sampel plat besi dibuat berukuran $5 \times 2 \times 0,2$ $\mathrm{cm}$. Bagian atas dari plat besi dilubangi dengan paku agar bisa digantung waktu proses perendaman. Plat besi dibersihkan menggunakan amplas, kemudian dicuci menggunakan akuades, dikeringkan, dan ditimbang untuk mengetahui berat awal plat besi.

\section{Pembuatan larutan induk inhibitor}

Larutan induk inhibitor 5000 ppm ekstrak daun gambir dibuat dengan cara melarutkan $5 \mathrm{~g}$ ekstrak daun gambir dalam labu ukur $1000 \mathrm{~mL}$ dengan akuades sampai tanda batas.

\section{Perendaman sampel plat besi (uji korosi)}

\section{Tanpa inhibitor}

Gelas kimia sebanyak 4 buah diisi dengan air laut masing-masing sebanyak $250 \mathrm{~mL}$. Plat besi yang sudah dipreparasi dimasukkan ke dalam masing-masing gelas kimia yang telah diisi air laut ( $\mathrm{pH}$ awal 7,9). Variasi waktu perendaman masing-masing plat besi 5, 10, 15, dan 20 hari. Besi yang telah direndam sesuai variasi hari diangkat, dicuci dengan akuades, dan dikeringkan. Plat besi tersebut kemudian diamplas dan ditimbang untuk mengetahui selisih berat awal dan berat akhir besi.

\section{Variasi konsentrasi inhibitor}

Gelas kimia sebanyak 4 buah diisi dengan air laut masing-masing $250 \mathrm{~mL}$. Larutan inhibitor dengan konsentrasi 1000 ppm dimasukkan ke dalam gelas kimia tersebut sebanyak $50 \mathrm{~mL}$. Plat besi yang sudah dipreparasi dimasukkan ke dalam gelas kimia yang telah diisi air laut dan larutan inhibitor. Plat besi direndam dengan variasi waktu $5,10,15$, dan 20 hari. Besi yang telah direndam sesuai dengan variasi hari yang ditentukan diangkat, dicuci, dan dikeringkan. Plat besi kemudian diamplas dan ditimbang untuk mengetahui selisih berat awal dan berat akhir besi. Selanjutnya dilakukan tahapan yang sama untuk konsentrasi larutan inhibitor 3000 dan 5000 ppm.

\section{Variasi pH air laut}

Gelas kimia sebanyak 4 buah diisi dengan air laut masing-masing $250 \mathrm{~mL}$. Air laut yang digunakan memiliki $\mathrm{pH}$ 3. Larutan inhibitor dengan konsentrasi 1000 ppm dimasukkan ke dalam gelas kimia tersebut sebanyak $50 \mathrm{~mL}$. Air laut dengan $\mathrm{pH}$ asam (3) dibuat dengan menambahkan $\mathrm{HCl} 1 \mathrm{~N}$ dan $\mathrm{pH}$ basa (9) dengan menambahkan $\mathrm{NaOH} 6 \mathrm{~N}$. Plat besi yang sudah dipreparasi dimasukkan ke dalam gelas kimia yang telah diisi air laut dan larutan inhibitor. Plat besi direndam dengan variasi waktu 5, 10, 15, dan 20 hari. Besi yang telah direndam sesuai dengan variasi hari yang ditentukan diangkat, dicuci, dan dikeringkan. Plat besi kemudian diamplas dan ditimbang untuk mengetahui selisih berat awal dan berat akhir besi. Selanjutnya dilakukan tahapan yang sama untuk $\mathrm{pH}$ air laut 6 dan 9 serta konsentrasi larutan inhibitor 3000 dan 5000 ppm.

\section{Pengujian}

Untuk menentukan kemampuan inhibitor ekstrak daun gambir dalam mengendalikan laju proses korosi pada sampel plat besi, dapat dilakukan perhitungan laju korosi besi dengan menggunakan Persamaan $1^{[6]}$.

$$
\begin{gathered}
r=\frac{W_{0}-W_{f}}{A x t} \\
r=\frac{g}{c m 2 \cdot h a r i}
\end{gathered}
$$

Keterangan :

$\mathrm{r} \quad=$ laju korosi

$\mathrm{W}_{0} \quad=$ berat awal besi $(\mathrm{g})$

$\mathrm{W}_{\mathrm{f}} \quad=$ berat akhir besi $(\mathrm{g})$

$\mathrm{A} \quad=$ luas permukaan plat besi yang terkorosi $\left(\mathrm{cm}^{2}\right)$

$\mathrm{t}=$ waktu (hari)

Luas permukaan plat besi yang terkorosi dapat dihitung dengan Persamaan 2 berikut:

$$
\begin{aligned}
A & =2(p x l+p x t+l x t)-2 \Pi r 2+2 \Pi r t \\
& =22,8628 \mathrm{~cm} 2
\end{aligned}
$$




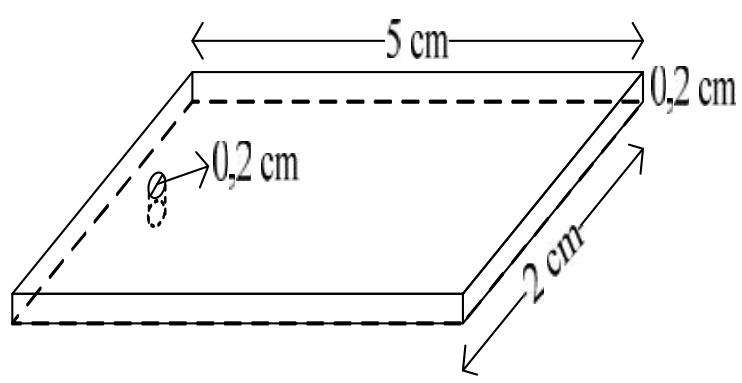

Gambar. 2. Mencari luas permukaan besi

Langkah selanjutnya adalah menentukan kemampuan inhibitor ekstrak daun gambir dengan menggunakan Persamaan $3^{[7]}$ :

$$
\% E=\frac{r_{1}-r_{2}}{r_{1}} \times 100 \%
$$

Keterangan :

$\% \mathrm{E}=$ efisiensi inhibis $(\%)$

$\mathrm{r}_{1} \quad=$ laju korosi tanpa inhibisi

$\mathrm{r}_{2} \quad=$ laju korosi dengan inhibitor

\section{HASIL DAN PEMBAHASAN}

\section{Pengaruh konsentrasi inhibitor ekstrak daun gambir dan waktu perendaman terhadap laju korosi besi}

Untuk mengetahui laju korosi besi dalam lingkungan yang menggunakan air laut sebagai media korosif, maka dilakukan uji korosi. Dalam metode ini berat awal sampel plat besi ditimbang, lalu direndam dalam media korosif air laut dengan cara digantung menggunakan tali dan dialirkan udara terus-menerus. Pengujian dilakukan pada temperatur lingkungan. Pada penelitian ini dilakukan perendaman plat besi tanpa inhibitor dan adanya variasi konsentrasi inhibitor 1000, 3000, dan 5000 ppm dengan waktu kontak 5, 10, 15, dan 20 hari. Pada perendaman plat besi tanpa inhibitor, dengan memvariasikan lamanya waktu kontak dalam media korosif, diperoleh data pada Tabel 1.

Dari hasil perhitungan pada Tabel 1 menunjukkan bahwa semakin lama waktu kontak maka berat plat besi semakin berkurang. Artinya besi yang terkorosi semakin banyak karena besi $(\mathrm{Fe})$ berubah menjadi ion $\mathrm{Fe}^{2+}$ yang larut dalam media air laut dan bereaksi dengan $\mathrm{OH}^{-}$membentuk $\mathrm{Fe}(\mathrm{OH})_{2}$. Tahapan proses korosi yang terjadi seperti pada persamaan reaksi berikut:

$\mathrm{Fe}_{(\mathrm{s})}+\mathrm{H}_{2} \mathrm{O}_{(\mathrm{l})}+1 / 2 \mathrm{O}_{2(\mathrm{~g})} \rightarrow \mathrm{Fe}^{2+}{ }_{(\mathrm{aq})}+2 \mathrm{OH}^{-}$

Ion $\mathrm{Fe}^{2+}$ yang terbentuk dapat teroksidasi kembali membentuk ion $\mathrm{Fe}^{3+}$ karena adanya oksigen berlebih dalam media air laut. Ion-ion $\mathrm{Fe}^{3+}$ tersebut kemudian bereaksi kembali dengan oksigen dan molekul-molekul air membentuk karat seperti pada persamaan reaksi berikut:

$2 \mathrm{Fe}(\mathrm{OH})_{2(\mathrm{~s})}+\mathrm{H}_{2} \mathrm{O}_{(\mathrm{l})}+1 / 2 \mathrm{O}_{2(\mathrm{~g})} \rightarrow 2 \mathrm{Fe}(\mathrm{OH})_{3(\mathrm{~s})}$

Pengurangan berat plat besi terjadi tanpa ataupun dengan penambahan larutan inhibitor. Semakin lama waktu kontak plat besi dengan media air laut, maka laju korosi juga semakin menurun. Hal ini disebabkan produk korosi $\mathrm{Fe}(\mathrm{OH})_{3}$ dapat menutupi permukaan plat besi membentuk lapisan pasif pada sisi katodik sehingga mempengaruhi reaksi reduksi di katoda. Jika reaksi di katoda terhambat, maka reaksi oksidasi besi di anoda juga terhambat.

Pengurangan berat sampel plat besi dan laju korosi pada perendaman plat besi tanpa inhibitor jauh lebih besar dibandingkan pada plat besi yang menggunakan larutan inhibitor. Semakin besar konsentrasi larutan inhibitor yang ditambahkan dalam media air laut, maka laju korosi semakin berkurang seperti yang telihat pada Gambar 3. Hal ini disebabkan molekul-molekul tanin yang teradsorpsi pada permukaan plat besi membentuk selaput pelindung pada permukaan plat besi tersebut. 
Tabel 1. Data hubungan waktu kontak terhadap laju korosi plat besi dalam media air laut tanpa dan dengan penambahan inhibitor ekstrak daun gambir pada $\mathrm{pH}$ 7,9

\begin{tabular}{cccccc}
\hline $\begin{array}{c}\text { Konsentrasi } \\
\text { Inhibitor } \\
(\mathbf{p p m})\end{array}$ & $\begin{array}{c}\text { Waktu } \\
\text { Perendaman, } \\
\mathbf{t}(\text { hari) }\end{array}$ & $\begin{array}{c}\text { Massa Besi } \\
\text { Awal, } \mathbf{W}_{\mathbf{~}}(\mathbf{g})\end{array}$ & $\begin{array}{c}\text { Massa Besi } \\
\text { Akhir, } \mathbf{W}_{\mathbf{f}}(\mathbf{g})\end{array}$ & $\begin{array}{c}\text { Kehilangan } \\
\text { Berat } \mathbf{( g )}\end{array}$ & $\begin{array}{c}\text { Laju Korosi, } \\
\mathbf{r}\left(\mathbf{g} / \mathbf{c m}^{\mathbf{2}} \mathbf{h a r i}\right)\end{array}$ \\
\hline \multirow{3}{*}{0} & 5 & 8,19 & 8,03 & 0,16 & 0,001400 \\
& 10 & 8,21 & 7,92 & 0,29 & 0,001268 \\
& 15 & 8,3 & 7,87 & 0,43 & 0,001254 \\
& 20 & 8,27 & 7,71 & 0,56 & 0,001225 \\
1000 & 5 & 7,19 & 7,07 & 0,12 & 0,001050 \\
& 10 & 7,24 & 7,01 & 0,23 & 0,001006 \\
& 15 & 7,43 & 7,1 & 0,33 & 0,000962 \\
& 20 & 7,53 & 7,11 & 0,42 & 0,000919 \\
3000 & 5 & 7,64 & 7,54 & 0,1 & 0,000875 \\
& 10 & 7,37 & 7,18 & 0,19 & 0,000831 \\
& 15 & 7,51 & 7,25 & 0,26 & 0,000758 \\
& 20 & 7,48 & 7,16 & 0,32 & 0,000700 \\
5000 & 5 & 7,42 & 7,34 & 0,08 & 0,000700 \\
& 10 & 7,3 & 7,15 & 0,15 & 0,000656 \\
& 15 & 7,55 & 7,36 & 0,19 & 0,000554 \\
& 20 & 7,21 & 6,98 & 0,23 & 0,000503 \\
\hline
\end{tabular}

Gugus fungsi yang berperan dalam interaksi antar molekul-molekul tanin dan permukaan besi membentuk selaput pelindung adalah gugus hidroksil. Gugus hidroksil pada molekul tanin dapat membentuk ikatan kovalen dengan logam besi. Hal ini didukung oleh fakta bahwa semakin banyak tanin yang teradsorpsi, semakin besar daya inhibisinya, sehingga laju korosi semakin berkurang.

Perendaman besi menggunakan inhibitor menghasilkan warna yang lebih pekat pada konsentrasi inhibitor tertinggi. Hal ini sesuai dengan sifat fisik tanin yaitu berwarna kekuningan sampai cokelat terang dan akan menjadi lebih gelap apabila terkena cahaya langsung atau dibiarkan di udara terbuka. Perendaman besi dalam media air laut tanpa inhibitor dan dengan penambahan inhibitor dapat dilihat pada Gambar 4.

Pada sampel plat besi yang telah direndam dalam media air laut tanpa dan dengan penambahan larutan inhibitor ekstrak daun gambir, tidak terjadi perbedaan yang signifikan. Permukaan plat besi tanpa ataupun dengan penambahan inhibitor sama-sama membentuk deposit/lapisan berwarna kecoklatan. Lapisan yang terbentuk lebih pekat pada plat besi yang direndam dalam media air laut dengan penambahan inhibitor. Namun lapisan yang terbentuk pada plat besi dalam media air laut tanpa penambahan inhibitor lebih mudah lepas apabila digosok dengan tangan. Ketika dilakukan proses pembersihan deposit/lapisan pada plat besi dalam media air laut dengan penambahan inhibitor, deposit/ lapisan tersebut sukar dibersihkan. Deposit/ lapisan tersebut harus digosok dengan sikat untuk membersihkannya.

\section{Pengaruh konsentrasi inhibitor ekstrak daun gambir dan waktu perendaman terhadap efisiensi inhibisi ekstrak daun gambir}

Dengan mengetahui laju korosi plat besi dalam media air laut tanpa dan dengan penambahan inhibitor, kita dapat menghitung efisiensi inhibisi ekstrak daun gambir tersebut. Efisiensi inhibisi ekstrak daun gambir ini dihitung dengan menggunakan Persamaan 3. Data efisiensi inhibisi ektrak daun gambir untuk tiap konsentrasi inhibitor berbeda, dapat dilihat pada Tabel 2. Dari data pada Tabel 2 dan Gambar 6 dapat dilihat semakin tinggi konsentrasi inhibitor ekstrak daun gambir yang digunakan, maka efisiensi inhibisi juga semakin meningkat. 


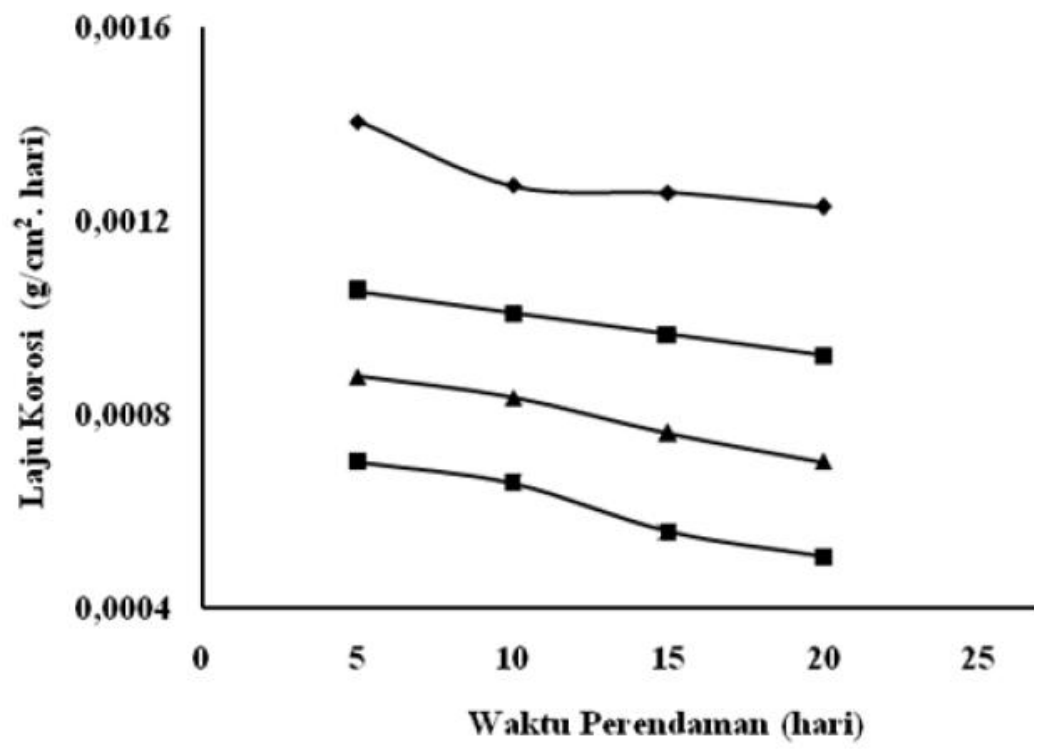

Gambar 3. Grafik hubungan variasi konsentrasi inhibitor dari ekstrak daun gambir menggunakan pelarut etanol-air terhadap laju korosi logam pada variasi waktu kontak (tanpa inhibitor (\$), inhibitor 1000 ppm (. $\ldots$, inhibitor 3000 ppm (... $\mathbf{\Lambda}$ dan inhibitor 5000 ppm (....

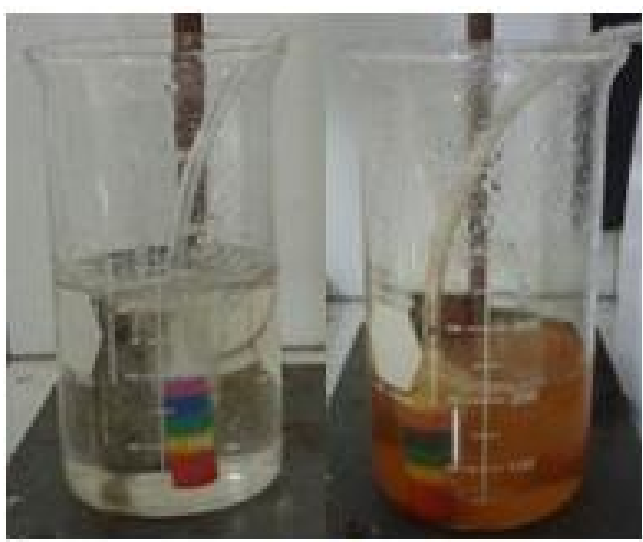

(a)

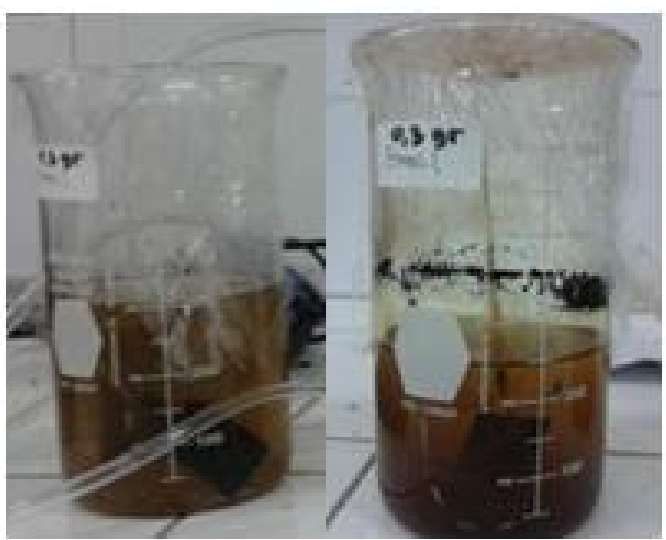

(b)

Gambar 4. Perubahan warna media air laut (a) tanpa inhibitor (b) dengan penambahan inhibitor

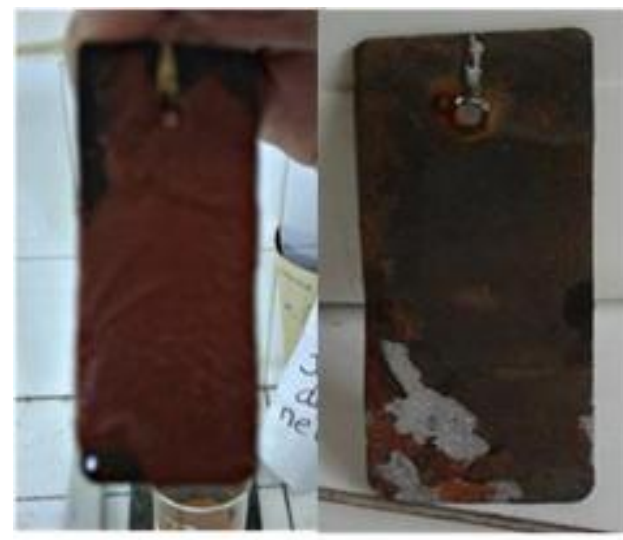

(a)

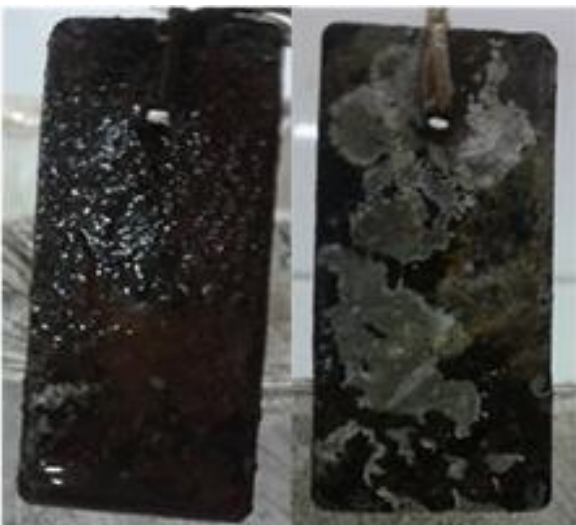

(b)

Gambar 5. Plat besi yang telah mengalami perendaman dalam media air lau (a) tanpa inhibitor (b) dengan penambahan inhibitor 
Peningkatan persen efisiensi inhibisi ini menunjukkan bahwa senyawa tanin memiliki potensi sebagai inhibitor korosi besi dalam media air laut. Persen efisiensi inhibisi tertinggi diperoleh pada konsentrasi inhibitor ektrak daun gambir 5000 ppm sebesar $60,345 \%$.

Pengaruh variasi pH media air laut terhadap laju korosi dan efisiensi inhibitor ekstrak daun gambir

Pengaruh variasi $\mathrm{pH}$ media air laut dan konsentrasi inhibitor terhadap laju korosi dan efisiensi inhibitor dapat dilihat pada Gambar 7, 8, dan 9. Semakin rendah $\mathrm{pH}$ maka laju korosi semakin meningkat, namun semakin menurun dengan meningkatnya konsentrasi inhibitor. Karena banyaknya bahan padat terlarut yang terdapat dalam air laut yang menyebabkan perubahan $\mathrm{pH}$, akan mempengaruhi laju korosi suatu bahan $\operatorname{logam}{ }^{[8]}$. Laju korosi meningkat dengan menurunnya $\mathrm{pH}$ karena $\mathrm{pH}$ yang rendah merupakan penyebab utama terjadinya korosi. Larutan yang bersifat asam ( $\mathrm{pH}$ rendah) menyebabkan reaksi antara besi dan larutan menjadi semakin besar seperti yang ditunjukkan pada reaksi berikut:

$2 \mathrm{Fe}(\mathrm{OH})_{2(\mathrm{~s})}+\mathrm{O}_{2(\mathrm{~g})}+\mathrm{H}^{+} \rightarrow 2 \mathrm{Fe}(\mathrm{OH})_{3(\mathrm{~s})}$

Pada kondisi basa, jumlah $\mathrm{OH}^{-}$yang berlebih tidak berpotensi membentuk $\mathrm{Fe}(\mathrm{OH})_{3}$ yang merupakan produk korosi. Hal ini dikarenakan sifat $\mathrm{OH}^{-}$dalam air adalah alkali yang menetralkan asam yang merupakan penyebab terjadinya korosi ${ }^{[9]}$.

Konsentrasi inhibitor yang rendah menyebabkan laju reaksi meningkat. Hal ini disebabkan jumlah tanin yang teradsorpsi sedikit sehingga kemampuan untuk melapisi logam besi kurang baik dan lapisan pelindung yang terbentuk tipis. Efisiensi inhibisi ekstrak gambir terbesar adalah $60,345 \%$ yang diperoleh pada konsentrasi inhibitor 5000 ppm dan waktu kontak 20 hari. Sedangkan pada $\operatorname{Asdim}^{[7]}$, efisiensi inhibisi baja dalam larutan asam sulfat 0,02 M menggunakan $200 \mathrm{ppm}$ ekstrak kulit manggis menghasilkan efisiensi inhibisi sebesar 48,79\%.

Tabel 2. Efisiensi inhibisi ekstrak daun gambir dengan konsentrasi inhibitor ekstrak daun gambir yang berbeda

\begin{tabular}{cccc}
\hline $\begin{array}{c}\text { Konsentrasi } \\
\text { Inhibitor } \\
(\mathbf{p p m})\end{array}$ & $\begin{array}{c}\text { Waktu } \\
\text { Perendaman } \mathbf{t}, \\
\text { (hari) }\end{array}$ & $\begin{array}{c}\text { Laju Korosi, } \mathbf{r} \\
\left(\mathbf{g} / \mathbf{c m}^{\mathbf{2}} \text { hari) }\right.\end{array}$ & $\begin{array}{c}\text { Efisiensi Inhibisi, } \\
\mathbf{\%} \mathbf{E}(\boldsymbol{\%})\end{array}$ \\
\hline 1000 & 5 & 0,001050 & 25 \\
& 10 & 0,001006 & 20,69 \\
& 15 & 0,000962 & 23,256 \\
3000 & 20 & 0,000919 & 26,744 \\
& 5 & 0,000875 & 37,5 \\
& 10 & 0,000831 & 34,483 \\
& 15 & 0,000758 & 39,535 \\
5000 & 20 & 0,000700 & 44,186 \\
& 5 & 0,000700 & 50 \\
& 10 & 0,000656 & 47,674 \\
& 15 & 0,000554 & 56,322 \\
\hline & $\mathbf{2 0}$ & $\mathbf{0 , 0 0 0 5 0 3}$ & $\mathbf{6 0 , 3 4 5}$ \\
\hline
\end{tabular}




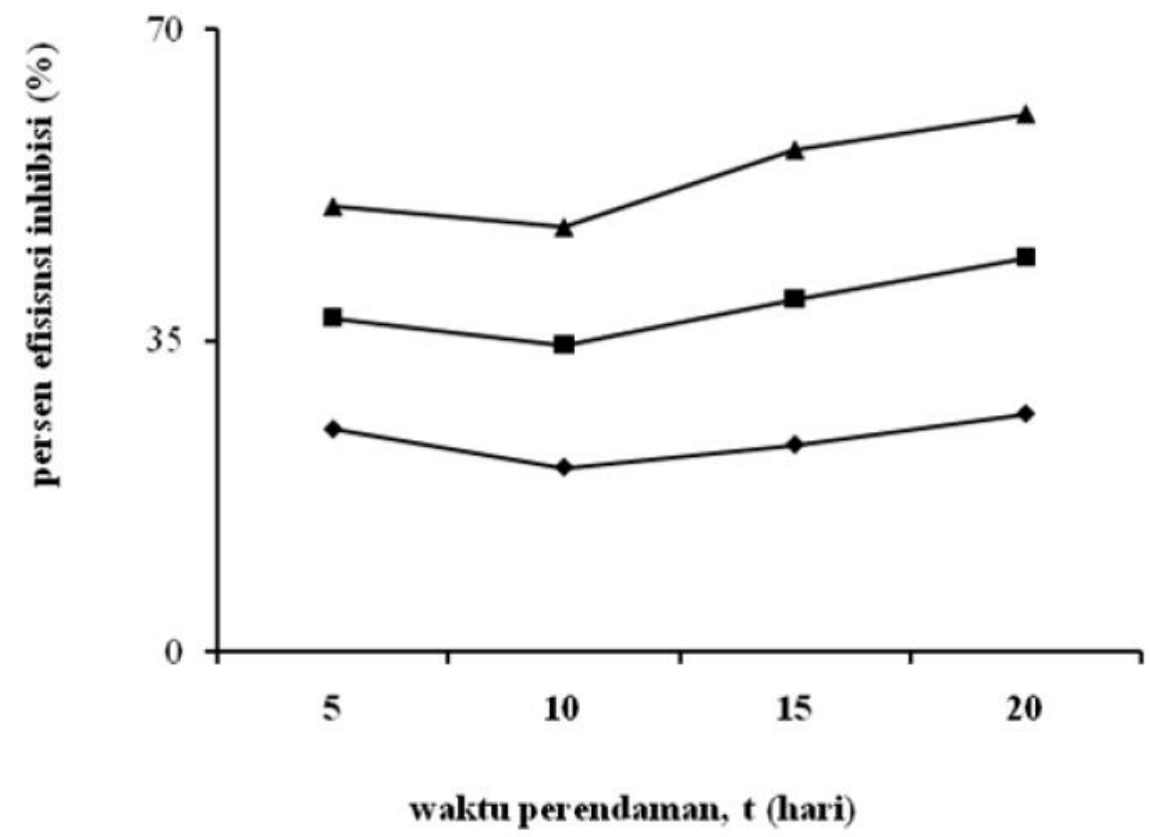

Gambar 6. Pengaruh konsentrasi inhibitor dan waktu perendaman terhadap efisiensi inhibisi ekstrak daun gambir (1000 ppm (.ム, 3000 ppm (... dan 5000 ppm(...)

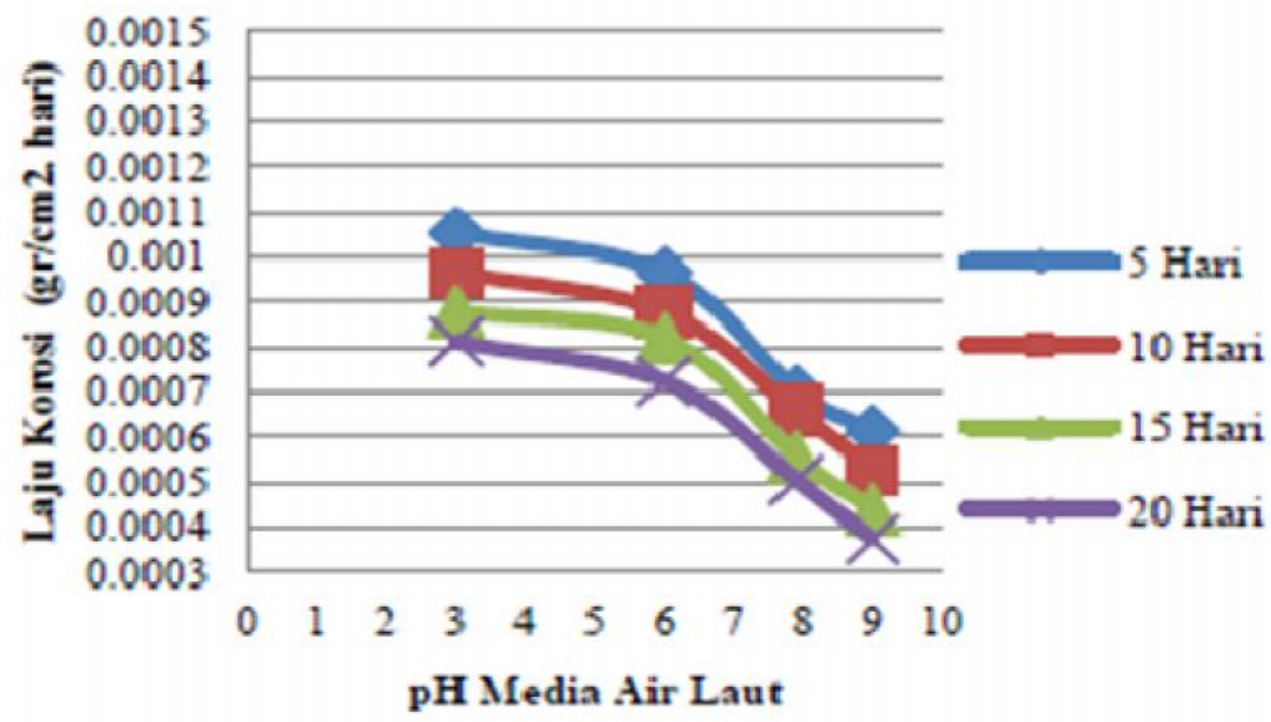

Gambar 7. Pengaruh variasi pH terhadap laju korosi pada konsentrasi inhibitor 1000 ppm 


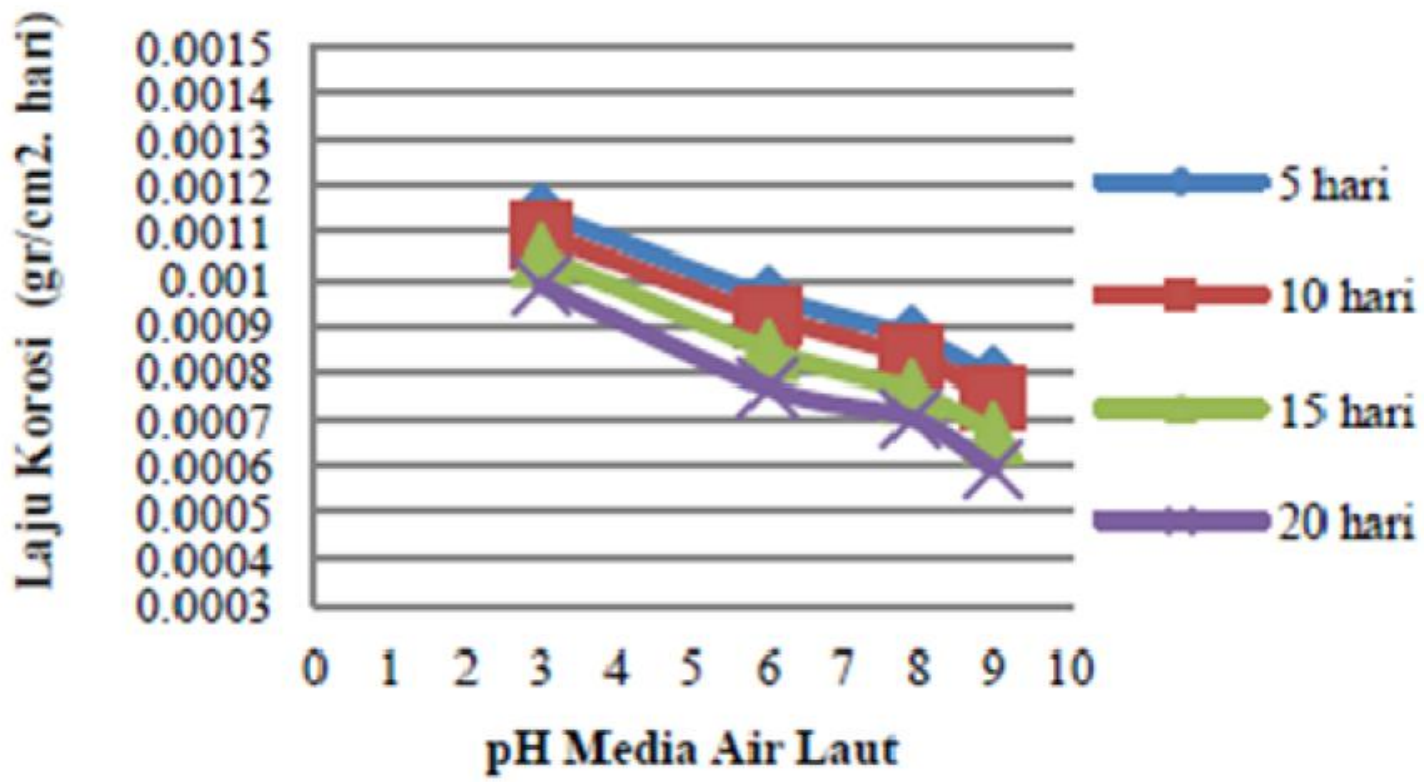

Gambar 8. Pengaruh variasi pH terhadap laju korosi pada konsentrasi inhibitor 3000 ppm

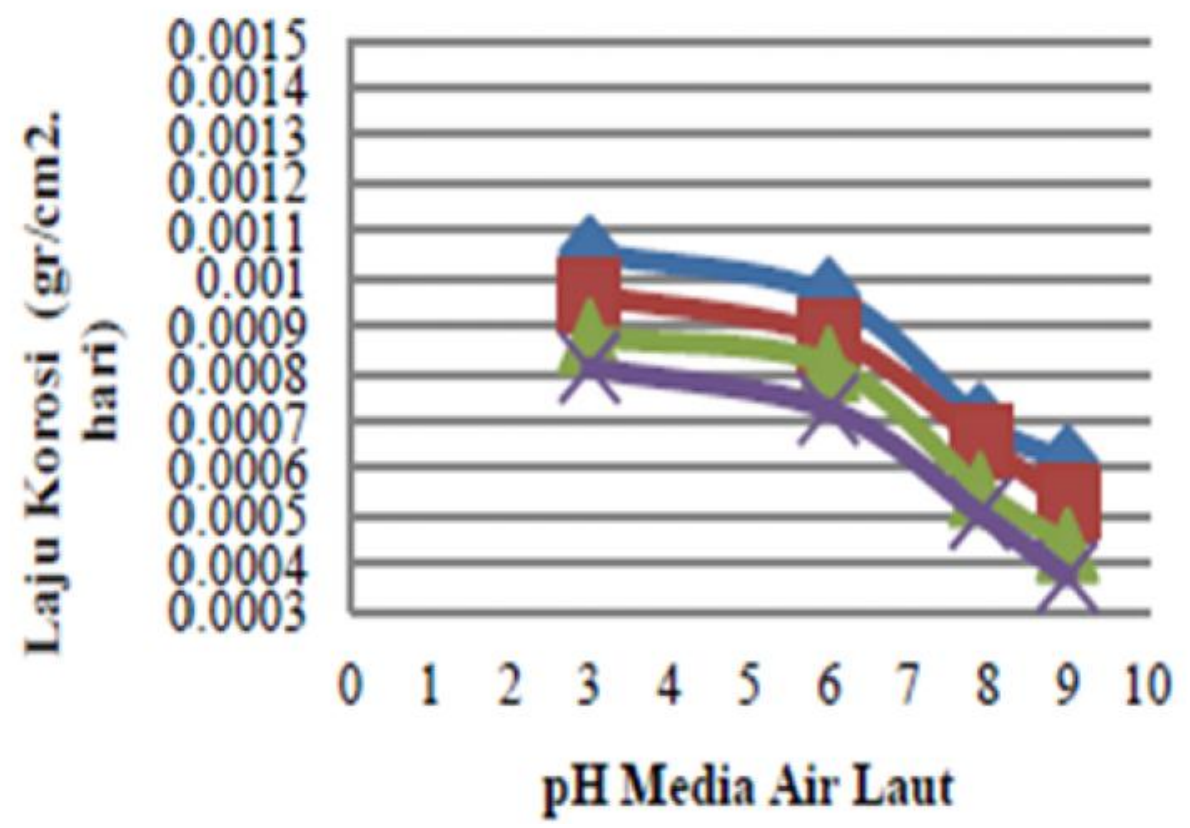

Gambar 9. Pengaruh variasi pH terhadap laju korosi pada konsentrasi inhibitor 5000 ppm

\section{KESIMPULAN}

Berdasarkan hasil penelitian, pengurangan massa plat besi semakin meningkat seiring bertambah waktu kontak antara plat besi dengan media air laut tanpa inhibitor. Namun laju korosi plat besi pada kondisi tersebut semakin menurun dengan bertambah waktu kontak. Dengan adanya penambahan inhibitor ekstrak daun gambir terjadi perubahan nilai laju korosi plat besi. Pengurangan massa plat besi jauh lebih kecil dengan semakin meningkatnya konsentrasi inhibitor ekstrak daun gambir yang digunakan. Begitu juga dengan nilai laju korosinya juga semakin rendah. Nilai laju korosi plat besi menurun dengan semakin lamanya waktu kontak antara plat besi dengan media air laut dengan penambahan inhibitor. Selain itu, semakin rendahnya $\mathrm{pH}$ media air laut, maka laju korosi akan semakin meningkat. Laju korosi terendah diperoleh pada konsentrasi inhibitor 5000 ppm 
dan variasi waktu kontak 20 hari yaitu $0,000503 \mathrm{~g} / \mathrm{cm}^{2}$.hari dalam media air laut dengan $\mathrm{pH}$ awal 7,9. Efisiensi inhibisi ekstrak gambir terbesar adalah $60,345 \%$ yang diperoleh pada konsentrasi inhibitor 5000 ppm dan waktu kontak 20 hari.

\section{UCAPAN TERIMA KASIH}

Terima kasih penulis ucapkan kepada Nikita Regina yang telah membantu dalam pelaksanaan penelitian ini. Selain itu, penulis juga mengucapkan terima kasih kepada pihak Lembaga Penelitian Universitas Riau yang telah mendanai pelaksanaan penelitian ini.

\section{DAFTAR PUSTAKA}

1. B. Hermawan, 2007, Ekstrak bahan alam sebagai alternatif inhibitor korosi, http://www.chem-is-try.org, 24 April 2012.

2. E. Sjostrom, Wood chemistry. fundamentals and apllications. Academic Press. New York, 1981.
3. R. Pambayun, M. Gardjito, S. Sudarmaji, dan K. Kuswanto, Kandungan fenol dan sifat anti bakteri dari berbagai jenis ekstrak produk gambir (Uncaria gambir roxb), Majalah Farmasi Indonesia., 18 (3), 141-146, (2007).

4. A. E. Hagerman, Tannin Handbook, Miami University, USA, 2002.

5. B. L. Browning, Methods of wood chemistry, Vol I, II. Interscience Publishers, New York, 1966.

6. M. Erna, Karboksimetil kitosan sebagai inhibitor korosi pada baja lunak dalam media air gambut, Jurnal Matematika dan Sains., 2(16), 106-110, (2011).

7. Asdim, Penentuan efisiensi inhibisi ekstrak kulit buah manggis (Garcinia mangostana $L$ ) pada reaksi korosi baja dalam larutan asam, Jurnal Gradien., 2 (3), 273-276, (2007).

8. T. Setiadi, Kimia air, pengolahan dan penyediaan air. ITB. Bandung, (2007).

9. D. E. Hathway, The condensed tannins. in wood extractives (Hillis W. E). Academic Press. New York, 1962. 